\title{
Comparison between Economic Factors Influencing Development in the Association of South-East Asian Nations Regional Bloc and the East African Community
} Judy Njeru: Masinde Muliro University of Science and Technology Department of Peace and Conflict Studies,
Kakamega, Kenya.

Pontian Okoth: Masinde Muliro University of Science and Technology Department of Peace and Conflict Studies, Kakamega, Kenya.

Frank K. Matanga: Masinde Muliro University of Science and Technology Department of Peace and Conflict Studies, Kakamega, Kenya.

\begin{abstract}
Regionalism in Africa has been pursued to foster economic growth and outgrowth. Despite the numerous efforts towards economic integration by the East African regional states, success has been limited. There is no comprehensive integration policy to cement the East African regional states. Although several authors have examined the influence of regionalism from various perspectives and regions, they have not addressed the EAC and the ASEAN in a comparative context. This knowledge gap motivated the current study whose specific objective was to assess the economic factors which influence development in the EAC and the ASEAN regional blocs. The study was guided by the Power Theories. It employed the concurrent mixed methods approach, incorporating the survey design for the quantitative component, and the exploratory design for the qualitative component. The study used both purposive and stratified random sampling to select respondents from members of the EAC Secretariat, delegates attending various EAC council and summit meetings, ASEAN diplomatic representatives within the EAC Partner States and officers from the Ministries of East African Community and Foreign Affairs. The study utilized primary data collected using questionnaires and interview guides.. The study established that The EAC member states have embraced similar policies on human development, social benefit and protection, across the region. The results of this study have demonstrated that, despite the numerous efforts of advancing economic integration by the East African regional states, real, tangible success is still an illusion. Pragmatic realization of mutual political trust needs to be embraced if the goal of economic integration is to be realized. The study recommends the development of a legislative and economic framework (laws, policies and guidelines) for Community Development within partner states as well as harmonization of democratization policies, processes and practices.
\end{abstract}

Vol. 1, No. 4, pp. 299-306

2018

DOI: 10.53935/2641-533x.v1i4.98

Corresponding Author: Judy Njeru

Funding: This study received no specific

financial support.

Article History:

Received: 1 October 2018

Revised: 29 October 2018

Accepted: 7 December 2018

Published: 28 December 2018

(C) 2018 by the authors; licensee Academic

Publishing Group

299

\section{Key words: Economic Integration, Regionalism, Functionalism, Neo-functionalism.}

\section{Introduction}

1.1. Background to the Study

Regional cooperation involves cooperation among distinct countries with a shared involvement in a particular matter and may admit "the implementation of joint projects, technical sector cooperation, common running of services and policy harmonization, and joint development of common natural 
resources" (Lee, 2002). Africa has adopted regional integration mainly because of its possible economic benefits. As Julian, Carrère, and Marcelo (2012) notes, African leaders have come to understand the benefits of regional integration in and cooperation through inter-regional policies, asylum-building, trade, and other matters of mutual interest. Moreover, the creative activity of regional blocs was seen as a way to rescue the continent from colonial and neo-colonial influences and enable it to effectively mesh with the developed world (Mulaudzi, 2006). It is not surprising that the continent has for decades initiated a kind of regional systems, principally along economic and political lines, aimed at integrating Africa to attain these benefits.

The organization (EAC) was instituted originally in 1967, it collapsed in 1977, and was revived on 7th July 2000. In 2008, after negotiations with the Southern Africa Development Community (SADC) and the Common Market (East African Trade Bloc Approves Monetary Union Deal. (2018). The EAC is an integral part of the African Economic Community (East African Community Political Federation, 2016).

In comparison, the Association of Southeast Asian Nations [Association of Southeast Asian Nations, 2015:] (Chalermpalanupap, 2008) is a political and economic organization of Ten Southeast Asian countries. Since its formation on August 8, 1967, by Indonesia, Malaysia, the Philippines, Singapore, and Thailand, Wikisource (2007) the organization's membership has expanded to include Brunei, Cambodia, Laos, Myanmar (Burma), and Vietnam. Association of Southeast Asian Nations (asean)| U.s (2018). Retrieved from https://www.uschamber.com/ association-southeast-asian-nations-asean). Its principal aims include accelerating economic growth, social progress, and sociocultural evolution among its members, alongside the protection of regional stability and the provision of a mechanism for member countries to resolve differences peacefully. (Asean, 2015), The Economist (2015)

\subsection{Statement of the Problem}

The overall structure of the ASEAN economies has changed since the adoption of the AEC Blueprint in 2007 with the growing importance of the services sector Political-Legal Structural Constraints to Politica (2018). The share of the services sector in the economy steadily increased to reach $50.2 \%$ in 2014 while both the industry and the agriculture sector's share declined and stood at $38.0 \%$ and $11.0 \%$ respectively. Growth in the region has been driven by an increasing share of foreign direct investment (FDI) inflows to the services sector, as well as a solid performance in the trade sector, contributing to the region's output expansion (Asean, 2015), (Asean Changes And Benefits From Integration: Report, 2018).

As ASEAN makes great economic strides, the EAC has faced many challenges. Nanilowo (2003) observes that, there is no comprehensive integration policy to cement the East African regional states. Developing one has not been easy. This is because the countries have had very different experiences and obstacles to deal with. Some members are only now starting to recover from the disruptive politics of military dictatorships and the painful experiences of ethnic conflicts. Each country, in dealing with such challenges has put the goals of regional economic development on hold. This study sought to assess how the ASEAN example can contribute to EAC's economic development.

\subsection{Objectives of the Study}

The specific objective of the study was to assess the economic factors which influence development in the ASEAN regional bloc and compare them with scenario obtaining in the EAC.

\section{Literature Review \\ 2.1. Economic Factors Influencing Development}

An increase of welfare has been recognized as a primary objective of economic integration. The increase of trade between member states of economic unions is meant to lead to the increase of the GDP of its members, and hence, to better welfare, as Langenhove (2004) explain.

The enthusiasm of the EAC to facilitate trade among its members is enshrined in Article 5 (2) of the Treaty establishing the East African Community which states that the first stage of EAC integration will be the formation of a Customs Union. The EAC Customs Union Protocol came into force in January 2005. The Customs Union has four major elements: (1) the establishment of a Common External Tariff (CET); (2) the establishment of EAC Rules of Origin (RoO) criteria, including Certificates of Origin and Simplified Certificates of Origin; (3) the internal elimination of tariffs for goods meeting the EAC RoO criteria and

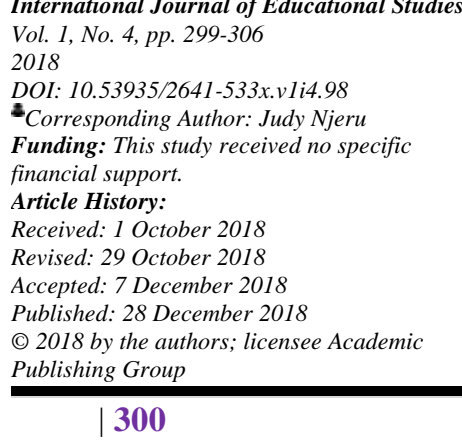


(4) the elimination of Non-Tariff Barriers (NTBs). The primary objective of the Protocol establishing the Customs Union is to facilitate inter and intraregional trade in goods. The Treaty establishing the East African Community then names as subsequent stages of EAC integration the establishment of a Common Market, then a Monetary Union and ultimately a Political Federation (The East African Integration: Achievements And Challenges (2018).

ASEAN on the other hand is built along three pillars (Asean, 2015) the ASEAN Political-Security Community (APSC), (Jakarta: ASEAN Secretariat, 2013) the ASEAN Economic Community (AEC), (Jakarta: ASEAN Secretariat, 2013) and the ASEAN Socio-Cultural Community (ASCC). (Jakarta: ASEAN Secretariat, 2013) ASEAN sought economic integration by creating the AEC by the end of 2015. This proved a common market. (Sim, "Introduction to the ASEAN Economic Community, 2012) The average economic growth of ASEAN's member nations during 1989-2009 was between 3.8\% and 7\%. This economic growth was greater than the average increment of the Asia-Pacific Economic Cooperation (APEC), which was $2.8 \%$ (The Jakarta Post, 2011).

Since 2007, ASEAN countries have gradually lowered their import duties to member countries. The target is zero import duties by 2016. Ministry of International Trade and Industry-Malaysia (2013). The ASEAN Framework Agreement on Trade in Services (AFAS) was taken at the ASEAN Summit in Bangkok in December 1995. (ASEAN. 2009) Under AFAS, ASEAN member countries enter into successive rounds of negotiations to liberalize trade in services with the aim of submitting increasingly higher levels of allegiance. At present, ASEAN has concluded seven packages of commitments under AFAS (ASEAN Secretariat, 2011). ASEAN has a Mutual Recognition Agreements (MRAs) for eight professions: physicians, dental practitioners, nurses, designers, engineers, accountants, surveyors, and tourism professionals. People in these professions are free to play in any ASEAN nation. [ASEAN Secretariat; World Bank, 2014]

\subsection{Theoretical Framework}

The theoretical aspect of economic integration shares some parallels with neoliberalism. However, here, the emphasis is placed on trade among member countries and the widening of markets through integration. Economic integration represents a set of concepts and theories explaining integration among countries based purely on economic grounds. Balassa (1987) recognized economic integration as a process and a state of affairs and defined it as measures designed to eliminate discrimination among economic units that belong to different countries.

The WAMZ was launched to complement WAEMU so that the two Monetary Unions can be merged into a single Monetary Zone with a common currency by the year 2020 (Sakyi \& Opoku, 2014). Beyond these theories, Dieter and Higgott (2003) stress the importance of what they call "regional monetary integration," which allows participating states to enter a process that will lead at least to the creation and stabilization of a common currency. Within this context, the integration process could be organized in four stages: the creation of a regional liquidity fund, regional monetary system, economic and monetary union, and political union. Here, the participating countries have to give up their sovereignty and independence in addition to each country's ability to issue its currency.

\section{Methodology}

This study adopted a mixed approach and the ex-post-facto design. Both quantitative and qualitative methods were employed. The area under study was within the member states of the EAC regional bloc comprising of; Kenya, Uganda, Tanzania, Burundi, Rwanda and South Sudan. South Sudan was however excluded from the study because of the prevailing internal conflicts and political instability which have delayed its full integration into the EAC. The EAC regional offices in Nairobi, Kampala, Arusha, Bujumbura, and Kigali provided an accessible population for this study. The ASIEN population for study comprised of personnel in the offices and residences of the high commissioners, diplomats, and ambassadors of these EAC member states. These are drawn from China, Indonesia, Japan, Thailand, Cambodia, Philippines, and Singapore. Table 1 summarizes the study population, sample, data collection tools and sampling strategies employed towards determination of each sample size. 
Table-1. Summary of sampling strategies, size and data collection tools.

\begin{tabular}{|c|c|c|c|c|}
\hline $\begin{array}{l}\text { Population } \\
\text { Components }\end{array}$ & Population (N) & Sample size (n) & $\begin{array}{l}\text { Sampling } \\
\text { strategy }\end{array}$ & $\begin{array}{l}\text { Data Collection } \\
\text { tool }\end{array}$ \\
\hline EAC Secretariat & 9 & 3 & $\begin{array}{l}\text { Stratified } \\
\text { purposive }\end{array}$ & $\begin{array}{l}\text { Interview } \\
\text { schedule }\end{array}$ \\
\hline $\begin{array}{l}\text { Delegates } \\
\text { attending } \\
\text { meetings }\end{array}$ & 600 & 180 & $\begin{array}{l}\text { Stratified } \\
\text { random }\end{array}$ & Questionnaire \\
\hline $\begin{array}{l}\text { Members of } \\
\text { EAC }\end{array}$ & 72 & 22 & $\begin{array}{l}\text { Stratified } \\
\text { random }\end{array}$ & $\begin{array}{l}\text { Focus group } \\
\text { discussion }\end{array}$ \\
\hline $\begin{array}{l}\text { Northern } \\
\text { Corridor } \\
\text { integration }\end{array}$ & 11 & 3 & $\begin{array}{l}\text { Stratified } \\
\text { purposive }\end{array}$ & Interview guide \\
\hline $\begin{array}{l}\text { Diplomatic } \\
\text { Missions }\end{array}$ & 207 & 62 & $\begin{array}{l}\text { Stratified } \\
\text { random }\end{array}$ & Questionnaire \\
\hline TOTAL & 899 & 269 & & \\
\hline
\end{tabular}

Determination of sample size from the target populated used the statistical procedure for sample size (SS) determination; the researcher computed the sample size at the $5 \%$ level of significance, with an error of 5\%. Using the Survey System (2017) SS calculator, this gave a sample size of 269 as summarized in Table 1. The data from the questionnaires were analysed by use of the Statistical Package for Social Sciences (SPSS) software Version

24.0. This software provided general statistical information about the participants investigated and assist in making inferences about the population (McNeill, 2005).

\section{Findings}

4.1. Eeconomic Factors Promoting EAC Growth and Development

Table 2 presents an analysis of economic factors promoting EAC growth and development.

Table-2. Economic factors promoting EAC growth and development.

\begin{tabular}{|c|c|c|c|}
\hline Economic Factors Promoting Eac Growth and Development & $\begin{array}{l}\text { Mean } \\
\text { Rating }\end{array}$ & $\begin{array}{l}\text { St. } \\
\text { Dev. }\end{array}$ & $\begin{array}{l}\% \\
\text { Rating }\end{array}$ \\
\hline $\begin{array}{l}\text { A Common External Tariff (CET) exists on imports from third-party } \\
\text { countries }\end{array}$ & 4.13 & 1.143 & 82.6 \\
\hline There is a duty-free trade between the member states & 4.17 & 0.974 & 83.4 \\
\hline There are Common customs procedures among the member states & 4.24 & 1.014 & 84.8 \\
\hline $\begin{array}{l}\text { Similar rates are applied to raw materials, intermediate products, and } \\
\text { finished goods }\end{array}$ & 3.62 & 1.401 & 72.4 \\
\hline $\begin{array}{l}\text { Current trade between the member countries is significant compared } \\
\text { to their external trade }\end{array}$ & 3.52 & 1.272 & 70.4 \\
\hline There is a progressively expanding regional market & 3.97 & 1.000 & 79.4 \\
\hline Patterns of regional development are already emerging & 3.89 & 1.045 & 77.8 \\
\hline $\begin{array}{l}\text { An intra-regional division of labour is developing that results in basic } \\
\text { import-processing relocating to the coast to supply the hinterland }\end{array}$ & 3.70 & 1.198 & 74.0 \\
\hline $\begin{array}{l}\text { Trade in goods and services have already increased as service } \\
\text { provision to member states is already important for all. }\end{array}$ & 3.42 & 1.116 & 68.4 \\
\hline $\begin{array}{l}\text { Integration in the region is helping to support its tourism potential } \\
\text { through integration with established regional circuits }\end{array}$ & 4.12 & 1.048 & 82.4 \\
\hline $\begin{array}{l}\text { There are signs of a business culture oriented to making profits } \\
\text { through economies of scale and not on protectionism. }\end{array}$ & 4.13 & 0.955 & 82.6 \\
\hline EAC negotiates with trade partners on behalf of all member countries & 3.79 & 1.218 & 75.8 \\
\hline $\begin{array}{l}\text { The large-scale manufacturing and agro-processing concerns are } \\
\text { broadly shared by the bulk of available labour }\end{array}$ & 3.94 & 1.071 & 78.8 \\
\hline
\end{tabular}

International Journal of Educational Studies Vol. 1, No. 4, pp. 299-306

2018

DOI: $10.53935 / 2641-533 x . v 1$ i4. 98

Corresponding Author: Judy Njeru

Funding: This study received no specific

financial support.

Article History:

Received: 1 October 2018

Revised: 29 October 2018

Accepted: 7 December 2018

Published: 28 December 2018

() 2018 by the authors; licensee Academic Publishing Group 
From Table 2, the analysis shows that the respondents' ratings vary from a minimum of $58.2 \%$ to a maximum of $84.8 \%$, on the respondents' concurrence that, "there are high investments on the conditions of life of the region's overwhelmingly rural poor, in the EAC region" and that, "there are Common customs procedures among the member states", respectively. These ratings are primarily modest, indicating that the EAC region is yet to achieve milestones in all the aspects of economic integration. The overall mean rating for the economic factors is computed at $\mathbf{7 5 . 4 \%}$, which can be interpreted as modest.

The factors rated lower by the EAC respondents are: Similar rates are applied to raw materials, intermediate products and finished goods (72.4\%); Current trade between the member countries is massive compared to their external trade (70.4\%); An intra-regional division of labour is developing that results in basic import-processing relocating to the coast to supply the hinterland(74.0\%), and; Trade in goods and services have already increased as service provision to member states is already essential for all $(68.4 \%)$.

Other factors rater low include: EAC negotiates with trade partners on behalf of all member countries (75.8\%); The establishment of a common market has created winners (numerous food producers and consumers on both sides of all borders) $(72.6 \%)$; There are high investments on the conditions of life of the region's overwhelmingly rural poor, in the EAC region $(58.2 \%)$; There are NO losers (smugglers and the customs, police and local government officers who currently benefit from bribery at and around the borders) in the border areas (66.8\%), and; The Common Market is seen as a step towards implementation of a common currency $(72.8 \%)$.

\subsection{Economic Factors Promoting ASEAN Growth and Development}

From Table 2, it can be observed that most of the factors rate very highly among the ASEAN respondents. The analysis gives an overall mean rating of $84.96 \%$, which can be interpreted as very high. The highest factor is the Common Market, which is seen as a positive step towards the achievement of a common currency, which is rated at $90.2 \%$. The lowest rated factor, rated at $78.4 \%$ is the fact that "An intraregional division of labor is developing that results in basic import-processing relocating to the coast to supply the hinterland." Figure 1 illustrates this analysis further.

Figure-1. Economic factors promoting ASEAN growth and development.

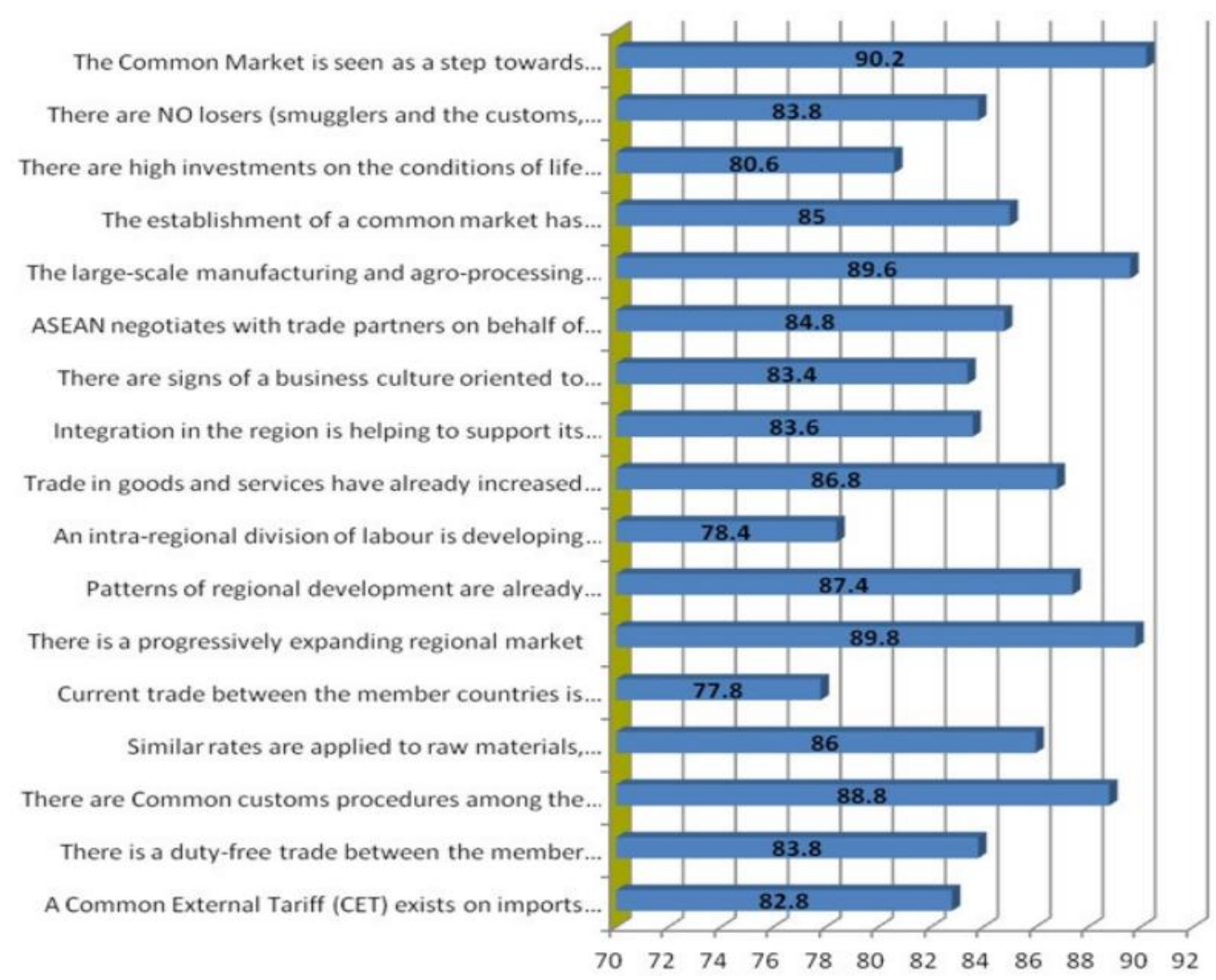


These findings are supported by some of the initiatives in economic integration that the ASEAN regional states have taken. For instance, ASEAN is built along three pillars (Asean, 2015) the ASEAN Political-Security Community (APSC), (Jakarta: ASEAN Secretariat, 2013) the ASEAN Economic Community (AEC), (Jakarta: ASEAN Secretariat, 2013) and the ASEAN Socio-Cultural Community (ASCC). (Jakarta: ASEAN Secretariat, 2013) ASEAN sought economic integration by creating the AEC by the end of 2015. This proved a common market. (Sim, "Introduction to the ASEAN Economic Community, 2012) The average economic growth of ASEAN's member nations during 1989-2009 was between 3.8\% and $7 \%$. This economic growth was higher than the average increment of the Asia-Pacific Economic Cooperation (APEC), which was 2.8\% (The Jakarta Post, 2011).

The ASEAN Free Trade Area (AFTA), which was set up on 28 January 1992, (Asian.org., 2009) includes a Common Effective Preferential Tariff (CEPT) to promote the large flow of goods between member countries. The Free flow of skilled laborers was realized through Mutual Recognition Agreements (MRAs) that allowed eight professions to work in any ASEAN nation was to come into effect in December 2015. Buranasomphop (2014) Free trade initiatives in ASEAN are spearheaded by the execution of the ASEAN Trade in Goods Agreement (ATIGA) and the Agreement on Customs. These arrangements are supported by work performed by several sector bodies to project and to execute free-trade measures, guided by the commissariat and the requirements of ATIGA and the Agreement on Customs.

In the aspect of Monetary Union, the concept of an Asian Currency Unit (ACU) started in the midriff of the nineties, before the 1997 Asian financial crisis. (Baby Steps To A Common Currency: 68) It is a proposed basket of Asian currencies, similar to the European Currency Unit, which was the forerunner of the Euro. The Asian Development Bank is responsible for exploring the feasibility and construction of the basket. [Baby Steps to a Common Currency: 68] [Asian Currency Unit]

\section{Conclusion and Recommendations \\ 5.1. Conclusion}

The ASEAN regional states have taken some steps to promote growth and development. The steps include a single market and production base, a competitive economic area, a region of equitable economic development, and a region that is fully integrated into the planetary economy. Since 2007, ASEAN countries have gradually lowered their import duties to member countries. The target is zero import duties by 2016. (Ministry of International Trade and Industry-Malaysia, 2013).

EAC member countries receive a problem of overlapping membership as they belong to more than one regional economic community. For example, Kenya belongs to the Common Market for Eastern and Southern Africa (COMESA), the East African Community (EAC) and the Intergovernmental Authority on Development (IGAD), New Partnership for Africa's Development (NEPAD) and African Caribbean Pacific/European Union (ACP/EU). Tanzania, Uganda and even other new members of EAC-Rwanda and Burundi have the same problem of overlapping memberships.

The multiple memberships are pricey to EAC member states and sometimes result in conflicting policies. This problem of overlapping memberships of competing groups needs to be addressed quickly to allow clear political commitments to the EAC. Also, ways should be found to increase the engagement of the private sector in the integration process as the EAC seeks to travel further for deeper integration.

The participation of consumer groups and other NGOs should also be encouraged as these groups can benefit from exploiting the opportunities for greater intra-regional trade. However, it should not be expected that all private sector groups will favor deeper regional integration. In some countries, farmers may fear low-cost competition from elsewhere in the region and may take quite a protectionist stance. However, the involvement of the private sector in other levels of integration, for example in common market, economic union and lastly political federation should be encouraged.

EAC member countries should cement their integration efforts by ensuring political stability, stepping up trade liberalization, opening up economies to competition and deepening their integration into the world economy, therefore giving a decisive boost to their integration drive. EAC member countries should put in place a mechanism to ensure policy credibility to the region. This is because investors need to have confidence that integration measures will not be overturned and that barriers to regional markets will not be instituted overnight. EAC member states should guarantee that political commitment is sustained by adhering to the provisions of the treaty and they should lay in place adequate capacity, both financial and 


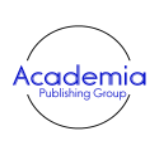

International Journal of Educational Studies Vol. 1, No. 4, pp. 299-306

2018

DOI: 10.53935/2641-533x.v1i4.98

Corresponding Author: Judy Njeru

Funding: This study received no specific

Funding: This study

financial support.

Article History:

Revised: 29 October 2018

Accepted: 7 December 2018

Published: 28 December 2018

(C) 2018 by the authors; licensee Academic

Publishing Group

| 305 human, for timely implementation of the treaty, projects, programmes, and policies. As well, they need to make sure that the various organs of the community and psychiatric hospitals are well coordinated in executing their obligations and obligations.

\subsection{Recommendations}

The study recommends the development of a legislative framework (laws, policies, and guidelines) for Community Development within partner states. There is a demand to strengthen the EAC structures and procedures to raise efficiency and potency. With a thorough understanding of the East African Community and its designs for future integration, it is significant to consider steps which may help aid the Community to reach its goals of getting a formidable economic union.

First and foremost, it is vital that the EAC not rush steps in integration only for the sake of seeming to make advancement. Integrative steps taken without care may do more damage than good in the long run and could risk splintering the EAC if negative consequences come after. It is critical to the success of integration plans that steps in the process are conducted in succession, as the later steps cannot be viably accomplished without a firm basis of initial reforms. In a similar vein, the more significant steps toward integration such as a monetary union and political federation should be regarded in a caution light and only tentatively considered while earlier steps in integration continue to advance. The event of the implementation of the euro currency in Europe should serve as some degree of warning to the East African Community, demonstrating that nation with differing economic conditions cannot be easily ingested into a single monetary union without extreme caution.

In looking towards emulating the success of the ASEAN region, the East African Community should apply several lessons from the nation's economic experience to its initiatives. The notable aspect of the EAC economy is the presence and activity of international corporations and organizations, which utilize EAC as the continental hub for business. The East African Community must put effort to achieve a similar situation, becoming another hub for economic activity in Central and Eastern Africa. As demonstrated through ASEAN impressive infrastructure network, the prioritization of infrastructure improvements in the EAC will similarly spur growth and development.

Additionally, the EAC should strive to achieve the same kind of economic diversification that has allowed ASEAN to prosper and reduce heavy reliance on the volatile agriculture sector. The EAC can also learn from some of the mistakes of ASEAN, as well. Inequality in some ASEAN states remains persistent. The East African Community should embrace its diverse peoples and aim for economic benefits to be distributed equally, giving all citizens of the EAC a higher chance for a better life.

\section{References}

Asean. (2015). Integration Report, AIR The ASEAN secretariat Jakarta. Asean: A Community of Opportunities Asean (2012) 'Asean Human Rights Declaration.

Asean Changes And Benefits From Integration: Report. (2018). Retrived from: http://www.nationmultimedia.com/business/Asean-changes-and-benefits-from-integra.

ASEAN Secretariat. (2011). We ${ }^{e e}$ re stronger when we're connected. ASEAN ICT.

Association of Southeast Asian Nations (asean) | U.s. (2018). Retrieved from: https://www.uschamber.com/association-southeast-asian-nations-asean.

Balassa, B. (1987). Economic integration; Entry in the new palgrave: A dictionary of economies (pp. 43-47). New York: Stockton Press.

Buranasomphop, D. (2014). A critical look at the ASEAN economic community scorecard. East Asia Forum.

Chalermpalanupap, T. (2008). Towards an East Asia community: The journey has begun. Home/Statement \& Communiques. The ASEAN and Regionalism in East Asia.

Dieter, H., \& Higgott, R. (2003). Exploring alternative theories of economic regionalism: From trade to finance in Asian Co-operation? Review of International Political Economy, 10, 430-454.

East African Community Political Federation. (2016). Three countries renew push for EAC political federation by 2016

Julian, G., Carrère, C., \& Marcelo, O. (2012). Regional Integration and Natural Resources Who Benefits? Evidence from MENA. Policy Research working paper; no. WPS 5970. World Bank. ( World Bank. 
Langenhove, K. (2004). From multilateralism to multiregionalism: What role for regional integration. In Global Governance UNU-CRIS Occasional Paper 2004/5.

Lee, M. (2002). Regionalism in Africa: A part of problem or a part of solution. Polis/R.C.S.P./C.P.S.R. Vol. 9, Numéro Spécial.

McNeill, G. (2005). Business \& economics - intereconomics 26, no. 1: 3-10 Routledge, 25 Apr.

Ministry of International Trade and Industry-Malaysia. (2013). MITI moving to new HQ. The Star (Malaysia) 17 November 2013.

Mulaudzi, C. (2006). The politics of regionalism in Southern Africa. Midland Publishers.

Nanilowo, A. (2003). Democratic governance, regional integration and development in Africa" DPMF Occasional Paper No. 11. Addis Ababa: Development Management Forum, No 2772, Washington DC 2002

Political-Legal Structural Constraints to Politica. (2018). Retrived from: http://erepository.uonbi.ac.ke/bitstream/handle/11295/59753/Njeru_Political\%20\%e.

Sakyi, D., \& Opoku, E. E. O. (2014). Regionalism and economic integration in Africa: A conceptual and theoretical perspective.

The Economist. (2015). The economist. Retrived from: www.economist.com/printedition/covers.

Wikisource. (2007). Constitution of the Kingdom of Thailand. Retrived from: https://wikisource.org/wiki/Wikisource

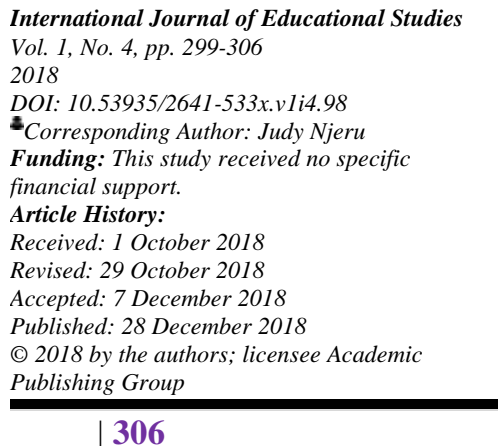

